\title{
40 jaar Krisis: Inleiding tot het jubileumnummer
}

René Gabriëls

Krisis 40 (1): 4-8

\begin{abstract}
The philosophical journal Krisis has been around for 40 years this year. The editorial board wanted to celebrate this by asking four editors from the past and the current editor-in-chief to shed light on the past, present and future of Krisis. In this introduction, some of the developments of the journal are briefly mentioned. Despite all kinds of changes that have taken place since Krisis was founded in 1980, the journal has remained true to itself.
\end{abstract}

DOI

$\underline{10.21827 / \text { krisis.40.1.37125 }}$

\section{Licence}

This work is licensed under a Creative Commons Attribution-NonCommercial 3.0 License (CC BYNC 3.0). 


\section{0 jaar Krisis: Inleiding tot het jubileumnummer René Gabriëls}

"Het initiatief tot dit blad is onder andere gegroeid vanuit de behoefte af te rekenen met het idee dat de filosoof er is om aan te tonen, dat 'we' uiteindelijk allemaal dezelfde taal spreken. Tegenover dat idee stelt Krisis dat van de filosofie als een strijdtoneel, waarbinnen het partij kiezen naast de rationele discussie één van de beslissende momenten vormt." Met deze woorden stelde de redactie van Krisis zich veertig jaar geleden voor aan haar lezers. De zeven filosofiestudenten die het tijdschrift oprichtten, positioneerden zich daarmee onmiddellijk in het filosofische landschap van destijds. Zij distantieerden zich uitdrukkelijk van wat in de academische filosofie bon ton was. Immers, voor de redactie impliceert partij kiezen "de creatieve verbondenheid met een beweging, in het geval van Krisis dus een historische band met de studentenbeweging, meer in het algemeen een oriëntatie op en betrokkenheid bij de linkse beweging in Nederland."

Naast de studentenbeweging waartoe de redacteuren behoorden, bestond de linkse beweging niet alleen uit de traditionele arbeidersbeweging, maar tevens uit de vrouwen-, homo-, milieuen krakersbeweging. De redactie beschouwde filosofie als partijdigheid in de theorie. Zij ging ervan uit dat de theorievorming wortelt in reële maatschappelijke tegenstellingen en strijd. Daarmee zette Krisis zich af tegen de academische filosofie indertijd, die zich beschouwde als een zichzelf bestuivende plant, een gesloten circuit oftewel "een kat in gevecht met zijn eigen staart."

Dit jubileumnummer kijkt niet alleen terug, maar richt ook het vizier op de toekomst. Hoe gaf Krisis de afgelopen veertig jaar vorm aan deze expliciete nexus van theorie en praktijk? Vertolkt het blad nog steeds een manier van filosoferen die zich onderscheidt van de mainstream? Valt uit de rijke geschiedenis van Krisis iets te leren voor de agenda van de filosofie?

Krisis heeft haar naam te danken aan de crisis van het marxisme eind jaren zeventig. Het marxistische vocabulaire bleek ontoereikend om de emancipatie van arbeiders in theoretisch opzicht te ondersteunen, laat staan die van vrouwen en homoseksuelen. Toentertijd waren velen van mening dat een filosofische praktijk die onder meer de vrouwen- en homobeweging wilde ondersteunen, beter een beroep kon doen op het poststructuralisme dan het marxisme. Zo werd 
Krisis in de jaren tachtig in de Nederlandse filosofie maatgevend voor de receptie van denkers als Gilles Deleuze, Jacques Derrida, Luce Irigaray, Julia Kristeva en Michel Foucault. Dat gebeurde niet zozeer op een exegetische wijze, zoals in het tijdschrift Te Elfder Ure, maar op meer eigengereide wijze. Niet door nauwgezet uit te leggen wat bekende buitenlandse filosofen zoal denken, maar door hun gedachtegoed voor politieke doeleinden naar de eigen hand te zetten. Krisis was niet zelden het strijdtoneel waar modernen en postmodernen met elkaar de degens kruisten. Daarbij werden vooral Jürgen Habermas en Jean-François Lyotard tegen elkaar uitgespeeld.

In Krisis werden niet alleen maatschappelijke en politieke vraagstukken gespiegeld aan filosofen van het Europese continent. Ook Angelsaksische filosofen, zoals Donald Davidson, John Rawls, John McDowell, Hilary Putnam en Richard Rorty werden kritisch tegen het licht gehouden. In de jaren tachtig kende Krisis nog tal van werkgroepen (bijvoorbeeld alternatieven in de wetenschap, vrouwenstudies en filosofie, politieke filosofie en cultuurtheorie) die roemruchte discussiebijeenkomsten organiseerden en zorg droegen voor themanummers over onder andere de Starnbergers, ecriture féminine, en stad en moderniteit.

Zoals Krisis aanvankelijk een bemiddelaar was tussen de academische filosofie en sociale bewegingen, zo vormde de Centrale Interfaculteit sinds 1960 binnen de universiteit een intermediair tussen de faculteiten waar de diverse wetenschappen zetelden. Zich niet boven maar tussen de disciplines bewegend konden filosofen in samenwerking met wetenschappers uit andere disciplines allerhande ethische en epistemologische vragen van verschillende wetenschapsdomeinen onderzoeken. Toen in 1987 de Centrale Interfaculteit werd opgeheven en omgevormd in de faculteit Wijsbegeerte, verdween daarmee een groot deel van de wetenschappelijke input en werd er een enorme impuls gegeven aan het navelstaren van de academische filosofie. Krisis bood tegengewicht door ook in de jaren negentig plaats te bieden aan artikelen die zich bewogen op de grens van filosofie en tal van andere wetenschappelijke disciplines, met name de politicologie, de sociologie en de culturele antropologie. Dat wierp zijn vruchten af in beschouwingen over het republikanisme van Hannah Arendt, het denken van grenzen door Pierre Bourdieu en de antropologisering van het wereldbeeld door Bruno Latour. Bovendien zette Krisis sindsdien de deur open voor de immer interdisciplinaire genderstudies, cultural studies en science and technology studies. 
Lange tijd werd Krisis in eigen beheer uitgegeven. Daaraan kwam in 1997 een einde toen uitgeverij Boom het tijdschrift in zijn fonds opnam. De uitgever had de ambitie om het aantal abonnees te vergroten. Toen dat niet lukte, lag het voor de hand om in 2000 met het filosofisch tijdschrift Kennis \& Methode te fuseren dat Boom eveneens uitgaf. Het in 1976 opgerichte en op de wetenschapsfilosofie gerichte blad publiceerde steeds vaker Krisis-achtige artikelen, hetgeen wellicht het gevolg was van ex-Krisis-redacteuren die het mede vormgaven. Door de fusie nam Krisis in 2000 de ondertitel van Kennis \& Methode over: Tijdschrift voor empirische filosofie. Maar omdat in de loop van de jaren steeds minder redacteuren zich konden identificeren met de empirische filosofie, veranderde in 2008 de ondertitel opnieuw, ditmaal in Tijdschrift voor actuele filosofie. Dat was tevens het jaar dat Krisis een tweetalig open accesstijdschrift werd. In het voorafgaande jaar hield de verbintenis met uitgeverij Boom op en verscheen de laatste papieren uitgave.

Dat Krisis naast Nederlandstalige ook Engelstalige artikelen ging publiceren was een concessie aan potentiële auteurs die in de dominante 'publish or perish'-cultuur steeds vaker te horen kregen dat artikelen die in het Engels geschreven zijn meer tellen dan die in moerstaal. Om dezelfde reden werd het een tijdschrift met een anonieme peer review. Niettegenstaande deze tegemoetkomingen aan een door het neoliberalisme geïnfecteerde academische wereld, is Krisis door deze veranderingen veel internationaler geworden. Een groot deel van de auteurs en reviewers komt uit het buitenland, waardoor het tijdschrift meer recht doet aan het transnationale karakter van veel van de actuele vraagstukken die het beschrijft (fascisme, kapitalisme, populisme, klimaatverandering, enzovoorts).

Krisis zoekt niet het licht van de eeuwigheid, maar belicht hedendaagse crisissen. Voor het in gedachten vatten van de tijdgeest wil het tijdschrift niet als een hegeliaanse uil van Minerva pas met het invallen van de duisternis zijn vleugels spreiden en over allerlei praktijken heen vliegen, maar zich veeleer dag en nacht als een soort woelrat daartussen bewegen. Het aan Plato's dialoog Timaeus ontleende begrip chora $(\chi \omega ́ \rho \alpha)$ is, met enige anti-platoonse fantasie, van toepassing op de ruimte die Krisis voor auteurs en lezers wenst te creëren. Met het begrip chora verwijst Plato naar een drempelwereld tussen de onveranderlijke ideeënwereld en de waargenomen wereld waarin alles voortdurend verandert. De hiërarchische binariteit (ideeën 
versus waarnemingen, zijn versus worden, afwezigheid versus aanwezigheid, passiviteit versus activiteit) wordt in deze tussenruimte constant ondermijnd. Het is een sfeer die ontvankelijk is voor wilde ideeën en tegelijkertijd creatief is in het ontsluiten van mogelijkheden voor een betere wereld. Chora duidt op een plek waar ruimte is voor een experimentele houding en waar het nieuwe in de wereld komt. Er wordt op een betere wereld geanticipeerd zonder daarvoor een blauwdruk te geven.

Ook na veertig jaar is 'tijdschrift voor actuele filosofie' een vlag die de lading goed dekt. Krisis besteedde de laatste jaren veel aandacht aan eigentijdse thema's als drones en data-activisme. Sinds haar oprichting is het blad zichzelf trouw gebleven, want in de uiteenlopende theoretische reflecties resoneren nog steeds praktische conflicten uit het leven van alledag. Toen studenten en docenten vanwege een conflict met universiteitsbestuurders in 2015 het Maagdenhuis van de Universiteit van Amsterdam bezetten, wijdde Krisis een nummer aan kritische reflecties over de toekomst van de universiteit. En als al een keer een filosoof in het tijdschrift centraal staat, dan wordt onmiddellijk gezocht naar een verbintenis met de actualiteit. Zo vormde in 2018 de tweehonderdste geboortedag van Karl Marx de aanleiding om deze revolutionaire denker te belichten vanuit marginale concepten in zijn werk of vanuit sociale werkelijkheden die vanuit een marxistisch perspectief vaak als marginaal worden beschouwd.

Het heugelijke feit dat Krisis veertig jaar is, wilde de redactie vieren door vier ex-redacteuren en een nog zittende redacteur te vragen om kritisch te reflecteren op het heden, verleden en de toekomst van het blad. Eerst komen twee redacteuren aan het woord die tot de oprichters van het tijdschrift horen. René Boomkens wijst erop dat de filosofiestudenten die in 1980 Krisis het levenslicht schonken hoopten dat hun tijdschrift een bijdrage zou leveren aan wat de Duitse studentenleider Rudi Dutschke ooit de lange mars door de instituties noemde door allerlei praktijken van de academische filosofie te kritiseren en veranderen. Ook al heeft de academische filosofie zich niet in de gewenste richting ontwikkeld, nog altijd is er volgens Boomkens voor Krisis een belangrijke rol weggelegd als intermediair tussen het academische onderzoek en het publieke debat. Karen Vintges betreurt dat tegelijk met de teloorgang van een pluraliteit aan paradigma's en stromingen die ooit kenmerkend was voor de universitaire filosofie in Nederland, er een staatsfilosofie dreigt te ontstaan die blind is voor structurele machtsongelijkheden. De radicale insteek van Krisis is daarom meer dan ooit nodig. Ido de Haan vraagt 
zich af of de genetische code van de problemen die Krisis aan de orde stelt draait om de vraag hoe op een praktijk-immanente wijze kan worden gefilosofeerd zonder dat daarbij de praktijktranscendente kritiek wordt versmaad. Aan de hand van vier variaties van filosofie als praktijk reconstrueert hij hoe het tijdschrift aan deze code in de loop van haar geschiedenis uitdrukking heeft gegeven. Gijs van Oenen beziet Krisis in het licht van het debat over identiteitspolitiek. Hij vindt dat het tijdschrift nooit politiek correct of belerend is geworden, iets wat hij de tot identiteitspolitie ontaarde hedendaagse identiteitspolitiek verwijt. Tivadar Vervoort spitst zich toe wat hij 'het epistemologische probleem van de kritische theorie' noemt. In het schipperen van Krisis tussen theorie en praktijk herkent hij een poging om politieke en sociale kwesties aan de kaak te stellen zonder zichzelf op een objectief standpunt boven de samenleving die het bekritiseert te plaatsen. De mogelijkheid van een dergelijke immanente kritiek beschouwt hij als typerend voor de kritische theorie in het algemeen en Krisis in het bijzonder.

\section{Biografie}

René Gabriëls is verbonden aan de Universiteit van Maastricht. Hij doet onderzoek naar voedselbanken en de verengelsing van het hoger onderwijs. Bovendien is hij redacteur van Krisis. 